\title{
Chemical composition, antioxidant and antifungal activities of essential oils and extracts from Plectranthus spp. against dermatophytes fungi
}

\author{
Composição química atividades antioxidante e antifúngica dos óleos essenciais e \\ extratos de "Plectranthus" spp. contra fungos dermatófitos
}

\begin{abstract}
ALVES, Fransérgio Américo Ribeiro ; MORAIS, Selene Maia de ${ }^{1,2,3}$; SOBRINHO, Antonio Carlos Nogueira ${ }^{3 *}$; SILVA, Isaac Neto Goes da ${ }^{1}$; MARTINS, Clécio Galvão²; SILVA, Antonio Adailson de Sousa ${ }^{4}$; FONTENELLE, Raquel Oliveira dos Santos ${ }^{5}$
\end{abstract}

\footnotetext{
${ }^{1}$ Universidade Estadual do Ceará, Faculdade de Veterinária, Programa de Pós-Graduação em Ciências Veterinárias, Fortaleza, Ceará, Brasil.

${ }^{2}$ Universidade Estadual do Ceará, Campus do Itaperi, Fortaleza, Ceará, Brasil.

${ }^{3}$ Universidade Estadual do Ceará, Rede Nordeste de Biotecnologia, Programa de Pós-Graduação em Biotecnologia, Fortaleza, Ceará, Brazil.

${ }^{4}$ Universidade Federal do Ceará, Faculdade de Medicina, Departamento de Fisiologia e Farmacologia, Fortaleza, Ceará, Brasil.

${ }^{5}$ Universidade Estadual Vale do Acaraú, Centro de Ciências Agrárias e Biológicas, Ceará, Brasil.

*Endereço para correspondência: caiosobrinho@yahoo.com.br
}

\section{SUMMARY}

Resistance to use antifungal drugs is a great concern seeking for scientists to discover new products to treat fungal infections. The aim of this study was to evaluate the antioxidant and antifungal activities of essential oils and extracts of Plectranthus grandis and Plectranthus ornatus against Trichophyton rubrum and Microsporum canis dermatophytes strains. Extracts were obtained from leaves by maceration in ethanol (96\%) during 7 days. The oils were obtained by hydrodistillation and analyzed by gas chromatography/ mass spectrometry. A total of 25 components were identified, as major constituents the sesquiterpenes $\beta$-caryophyllene, $\alpha$-copaene, germacrene, $\beta$-caryophyllene and caryophyllene oxide. Antioxidant activities were evaluated using DPPH scavenging assay and antifungal action was determined by the broth microdilution method. The decocts obtained from the extraction of essential oil presented a greater antioxidant action when compared with the essential oils, with $\mathrm{IC}_{50}$ values of 12.35 $\mu \mathrm{g} / \mathrm{mL}$ and $15.69 \mu \mathrm{g} / \mathrm{mL}$ to $P$. ornatus and $P$. grandis, respectively. Natural products presented significant antifungal activity, with MIC values ranging from $0.078 \mathrm{mg} / \mathrm{mL}$ to 0.31 $\mathrm{mg} / \mathrm{mL}$ for all strains. The synergistic activity between Plectranthus spp. extracts and ketoconazole demonstrated a fungal growth inhibitory action when combined with a standard antifungal drug, indicating its potential for use in preventive veterinary medicine to treat dermatophytoses.

Keywords: arthrodermataceae, dermatophytoses, lamiaceae, small carnivores

\section{RESUMO}

A resistência ao uso de drogas antifúngicas é uma grande preocupação para os cientistas, que buscam descobrir novos produtos para tratar infecções fúngicas. O objetivo deste estudo foi avaliar as atividades antioxidantes e antifúngicas de óleos essenciais e extratos de Plectranthus grandis e Plectranthus ornatus contra Trichophyton rubrum e Microsporum canis, fungos dermatófitos. Extratos foram obtidos a partir de folhas por maceração em etanol (96\%) durante 7 dias. Os óleos essenciais foram obtidos por hidrodestilação e analisados por cromatografia gasosa/espectrometria de massa. Um total de 25 componentes foram identificados, como constituintes principais, os sesquiterpenos $\quad \beta$-cariofileno, a-copaene, 
germacrene, $\beta$-cariofileno e óxido de cariofileno. As atividades antioxidantes foram avaliadas usando o teste de eliminação de DPPH e a ação antifúngica foi determinada pelo método de microdiluição de caldo. Os decoctos obtidos a partir da extração de óleo essencial apresentaram uma maior ação antioxidante quando comparados com os óleos essenciais, com valores de $\mathrm{IC}_{50}$ de $12,35 \mu \mathrm{g} / \mathrm{mL}$ e 15,69 $\mu \mathrm{g} / \mathrm{mL}$ para $P$. ornatus e $P$. grandis, respectivamente. Os produtos naturais apresentaram atividade antifúngica significativa, com valores de MIC variando de $0,078 \mathrm{mg} / \mathrm{mL}$ a $0,31 \mathrm{mg} / \mathrm{mL}$ para todas as cepas. A atividade de sinergismo entre extratos de Plectranthus spp. e cetoconazol demonstrou uma ação de inibição do crescimento fúngico, quando da combinação com um fármaco antifúngico padrão, indicando seu potencial de uso em medicina veterinária preventiva para tratar dermatofitoses.

Palavras-chave: arthrodermataceae, dermatofitose, lamiaceae, pequenos carnívoros

\section{INTRODUCTION}

The problem of antifungal resistance is a major concern in clinical practice, mainly due to the indiscriminate use of antimicrobial drugs, which interferes with therapeutic safety. New therapies are therefore needed against pathogenic fungi. Researchers aim to discover new antifungal drugs either by testing already existing medical compounds and compounds from natural sources such as plants, marine organisms, and microorganisms (SANGLARD, 2016). Plectranthus L'Hér (Lamiales: Lamiaceae) is a genus commonly found in Brazil Northeast region containing about 300 species distributed in the world tropical regions (LUKHOBA et al., 2006). In a previous study the essential oil of Plectranthus amboinicus has been showed antimicrobial activity against Gram-positive and negative bacteria strains and Candida albicans and $C$. tropicalis yeasts by the broth microdilution and agar diffusion methods. This activity might be due to the presence of two major monoterpenoid compounds, carvacrol and camphor (ERNY-SABRINA et al., 2014). The oil of $P$. barbatus is reportedly effective against two Cryptococcus neoformans strains (SANTOS et al., 2015).

Antimicrobial activity of Plectranthus sp. has already been reported, but activity against fungal strains isolated from animals is rarely described. Among the significant diseases in veterinary medicine, dermatophytoses are skin mycoses caused by fungi belonging to the genera Trichophyton, Epidermophyton and Microsporum, with a high affinity for keratinizined tissues (BOUCHARA et al., 2017). Such fungi have shown strong resistance to conventional treatment, so Plectranthus spp. extracts could be viable alternatives because they present bioactive compounds in their composition, such as phenolic compounds.

The search for natural products with biological potential for the treatment of infectious diseases is important, especially for fungal infections. $T$. rubrum and $M$. canis, which cause skin diseases in humans and animals, is an alternative that aims to reduce the side effects of commercial antifungal compounds and the development of resistant fungi (BOUCHARA et al., 2017).

In this context, this study evaluated the antioxidant and antifungal activities from extracts and essential oils of $P$. grandis and $P$. ornatus against dermatophytes fungi Trichophyton rubrum and Microsporum canis. 


\section{MATERIAL AND METHODS}

Leaves of Plectranthus grandis and Plectranthus ornatus were collected in the Francisco José de Abreu Matos Medicinal Plant Garden at Federal University of Ceará. The plants were identified and samples deposited in the Prisco Bezerra Herbarium of the same university, with numbers 28377 ( $P$. grandis) and 31929 ( $P$. ornatus). Extracts were obtained from leaves by maceration in ethanol (96\%) during 7 days. The solvent was evaporated in a rotary evaporator to obtain crude extracts: ethanol extract from Plectranthus leaves (EEPGL) and ethanol extracts from Plectranthus ornatus leaves (EEPOL).

Essential oils were obtained by hydrodistillation in a Clevenger apparatus, with heating the leaves in water during 3 hours. In this process, decoct (water solution remaining in the distillation flask) and hydrolate (condensed water that held the essential oils) were also obtained. The decoct obtained from essential oil extraction, after freezing, was lyophilized at an average temperature of $-51^{\circ} \mathrm{C}$, at negative pressure in a Liobras model L101 freeze dryer. The lyophilized decoct was extracted with ethyl acetate $(4 \times 50 \mathrm{~mL})$ and the ethyl acetate solution was dried with $\mathrm{Na}_{2} \mathrm{SO}_{4}$ and rota-evaporated to remove the solvent.

The chemical analysis of the constituents of essential oils was performed by gas chromatography combined with mass spectrometry (GCMS-FID) in a Shimadzu QP-2010 apparatus using the following conditions: column: DB-5 MS (Agilent, Part No. 122-5532); coated capillary column of fused silica $(30 \mathrm{~m} \times 0.25 \mathrm{~mm}$ x $0.25 \mu \mathrm{m})$; carrier gas: $\mathrm{He}$, at a flow rate of $1 \mathrm{~mL} / \mathrm{min}$ in constant linear velocity mode; injector temperature: $250^{\circ} \mathrm{C}$ in split mode (1: 100); and detector temperature: $250^{\circ} \mathrm{C}$. The column temperature was programmed from $35-180^{\circ} \mathrm{C}$ at $4{ }^{\circ} \mathrm{C} / \mathrm{min}$, then 180 $-280^{\circ} \mathrm{C}$ at $17^{\circ} \mathrm{C} / \min$ and $280^{\circ} \mathrm{C}$ for 10 min. The mass spectra were obtained with electron impact of $70 \mathrm{eV}$. The injected sample volume was $1 \mathrm{~mL}$. The compounds were identified by their retention indexes by gas chromatography compared to known compounds for the type of column used, and by comparison of their mass spectra with those present in the database of the NIST's virtual library and spectra published in the literature (ADAMS, 2012).

The analysis is based on visual observation of color changes or precipitate formation after addition of specific reagents to the plant extracts (MATOS, 2009; SIMÕES et al., 2010).

The Brand-Williams method (1995) was used, by placing $3.9 \mathrm{~mL}$ of a methanol solution $\left(6.5 \times 10^{-5} \mathrm{M}\right.$ DPPH free radical) in test tubes. Then $0.1 \mathrm{~mL}$ of the methanol extract solution was added to each tube, with nine sample concentrations $(250 \mathrm{mg} / \mathrm{mL}-0.025$ $\mathrm{mg} / \mathrm{mL}$ ). Tests were performed in triplicate for each concentration. Absorbance was measured with a Spekol spectrophotometer at a wavelength of $515 \mathrm{~nm}$. Results were used to calculate scavenging rate of the sample in percent $(\mathrm{SR} \%)$, using the formula: $\mathrm{SR} \%=\left(\mathrm{A}_{\mathrm{DPPH}}-\mathrm{A}_{\mathrm{SAMPLE}} /\right.$ $\left.A_{\text {DPPH }}\right) \times 100$, where $A_{\text {SAMPLE }}$ is the absorbance of the sample after 60 minutes. BHT (butylated hydroxytoluene) and quercetin were used as positive control. These values were applied in the Origin 7.0 statistical program to calculate the concentration that inhibited $50 \%$ of free radical solution $\left(\mathrm{IC}_{50}\right)$. 
T. rubrum strains were obtained from the Mycology Center of Recife. $M$. canis strains were isolated from dogs treated at the Veterinary Hospital of State University of Ceará. Minimum inhibitory concentration (MIC) was determined by the microdilution broth method in accordance with the Clinical and Laboratory Standards Institute M38-A guidelines (CLSI, 2008). Minimum fungicidal concentration (MFC) was determined according to Fontenelle et al. (2007). Extracts were prepared in DMSO and essential oil in mineral oil in concentrations ranging from 2.5 to $0.003 \mathrm{mg} / \mathrm{mL}$.

The inoculum was prepared from strains grown on potato dextrose agar for 5 days at $35^{\circ} \mathrm{C}$. Fragments of dermatophytes fungi were transferred to tubes containing $9 \mathrm{~mL}$ of saline to obtain a turbidity equivalent to the standard $5 \times 10^{4} \mathrm{~mL}^{-1}$ or 0.5 on the McFarland scale. The suspensions were diluted 1:5, both with Roswell Park Memorial Institute (RPMI) 1640 medium with L-glutamine, without sodium bicarbonate (Sigma Chemical Co., St. Louis, Mo.), buffered to $\mathrm{pH} 7.0$ with $0.165 \mathrm{M}$ morpholinepropanesulfonic acid (MOPS) (Sigma Chemical Co., St. Louis, Mo.), to obtain inoculum concentration of approximately $5 \times 10^{4}$ CFU. $\mathrm{mL}^{-1}$ (CLSI, 2008).

It was performed in 96-well plates. Controls for growth and sterility of the wells were included for each tested strain. Plates were incubated at $37{ }^{\circ} \mathrm{C}$ and were read after 5 days for dermatophyte fungi. All tests were run in duplicate and MIC was defined as the lowest concentration able to inhibit $100 \%$ of visible fungal growth. The minimum fungicidal concentration (MFC) was determined by subculturing $100 \mu \mathrm{L}$ of the well solution without turbidity on potato dextrose agar at $28^{\circ} \mathrm{C}$.
The interaction of the ketoconazole with $P$. grandis and $P$. ornatus extracts was evaluated by the checkerboard method, expressed as the sum of the fractional inhibitory concentration (FIC) index for each sample, representing the sum of the FICs of each drug tested, where the FIC is determined for each drug by dividing the MIC of each drug when used in combination by the MIC of each drug when used alone. Initially, $50 \mu \mathrm{L}$ RPMI culture was added to all 96 wells. $50 \mu \mathrm{L}$ of serial dilutions of plant extracts was added to the medium. Then, $50 \mu \mathrm{L}$ of ketoconazole was placed in different concentrations, and $100 \mu \mathrm{L}$ of inoculum was added to all wells. The inoculum alone was used as negative control and ketoconazole as positive control. Dermatophyte plates are incubated at $36^{\circ} \mathrm{C}$ during 10 days.

This fractional inhibitory concentration index (FICI) was calculated by adding the FIC of drug $A$ to the FIC of antibiotic B, where A represents the samples of $P$. grandis and $P$. ornatus products and $\mathrm{B}$, ketoconazole. The FICI of drug $\mathrm{A}=\mathrm{MIC}$ of drug $\mathrm{A}$ in combination/MIC of drug A alone, while the FIC of drug B = MIC of drug $\mathrm{B}$ in combination/MIC of drug $\mathrm{B}$ alone, and the FICI $=$ FIC of drug A + FIC of drug B. Synergism was defined as FICI $\leq 0.5$, additive effect when $0.5<$ FICI $\leq$ 1.0 , indifference when $1.0<\mathrm{FICI} \leq 4.0$, and antagonism when FICI $>4.0$ (WHITE et al., 1996, SOBRINHO et al., 2016).

All assays were carried out in triplicates. The data analyses were expressed as mean \pm standard deviation (SD). One-way ANOVA with the Tukey was determined with GraphPad Prism software 5.0 (GraphPad Software, San Diego, CA). Significance of difference was accepted at $\mathrm{P}<0.05$. 


\section{RESULTS AND DISCUSSION}

Phytochemical tests of leaf ethanol extracts from Plectranthus species revealed the presence of tannins and favonoids in all extracts; flovone and saponins for EEPGL; and steroids in EEPOL (Table 1). Therefore, it is likely that the antioxidant and antifungal potential of such compounds are responsible for the relevant results of the leaf extracts.

Table 1. Phytochemical tests of Plectranthus spp. ethanol extracts

\begin{tabular}{lcc}
\hline \multirow{2}{*}{ Class of Compounds } & \multicolumn{2}{c}{ Plant extracts } \\
\cline { 2 - 3 } & EEPGL & EEPOL \\
\hline Phenols (Condensed tannins) & + & + \\
Flavonoids & + & + \\
Flavonols & + & - \\
Free sterols & - & + \\
Saponins & + & - \\
\hline
\end{tabular}

EEPGL $=$ Ethanol extract of Plectrantus grandis leaves; EEPOL $=$ Ethanol extract of Plectrantus ornatus leaves. $(-)=$ negative result.

Essential oils of $P$. grandis (EOPG) and $P$. ornatus (EOPO) presented 25 constituents, which were identified by CG-MS-FID, through the analysis of mass spectra in comparison with literature data and Kovat's indexes (ADAMS, 2012). In $P$. grandis species, $\beta$ caryophyllene $\quad(38.25 \%), \quad \alpha$-copaene $(13.23 \%)$ and germacrene $(11.38 \%)$ were the main constituents. In P. ornatus the main components were caryophyllene oxide $(61.74 \%)$ and $\beta$-caryophyllene (10.65\%) (Table 2).

The constituents present in Plectranthus spp. oils were similar to those found by previous study (ALBUQUERQUE et al., 2007), except for the absence of oxygenated monoterpenes such as thymol and eugenol in our study. Nevertheless, the observed variations in the composition of the oils can be attributed to factors such as soil and weather, which were different in this study compared to other studies of Thymus hyemalis (MARTINEZ et al., 2005) and Lippia graveolens (CALVO-IRABIEN et al., 2014). Caryophyllene oxide was the major compound in EOPO, while in EOPG, $\beta$-caryophyllene, $\alpha$-copaene and germacrene $\mathrm{D}$ were the most abundant. The absence of oxygenated monoterpenes could explain the low antioxidant activity. However, ethanol extracts and decocts of the essential oils extracts from the leaves showed a higher antioxidant capacity in comparison to quercetin, the standard flavonoid.

The antioxidant capacity is evaluated to different methods, which depends on different generators of free radicals. The assay using free radical DPPH (1,1diphenyl-2 picrylhydrazyl) exhibit the ability to scavenge the radical through the variation of absorbance obtained for a stoichiometric color loss of the radical solution in the presence of antioxidant substances present in the extract samples (SOBRINHO et al., 2016). 
Table 2. Percent composition of the essential oils from Plectranthus spp.

\begin{tabular}{|c|c|c|c|c|}
\hline Constituent & IK (literature) & IK (calculated) & $\begin{array}{l}\text { P. grandis } \\
\text { Yield (\%) }\end{array}$ & $\begin{array}{l}\text { P ornatus } \\
\text { Yield (\%) }\end{array}$ \\
\hline$\alpha$-Pinene & 932 & 934 & 3.72 & - \\
\hline$\beta$-Pinene & 979 & 971 & 0.66 & - \\
\hline Myrcene & 998 & 994 & 2.04 & - \\
\hline$o$-Cymene & 1024 & 1022 & - & 1.79 \\
\hline 1,8-Cineole & 1026 & 1029 & 0.73 & - \\
\hline Ocimene (E)- $\beta$ & 1044 & 1037 & 1.30 & - \\
\hline Terpinen-4-ol & 1177 & 1138 & - & 6.20 \\
\hline Terpinen-4-ol acetate & 1300 & 1359 & - & 3.57 \\
\hline$\alpha$-Copaene & 1376 & 1385 & 11.38 & 1.94 \\
\hline$\beta$-Bourbunene & 1387 & 1394 & - & 4.54 \\
\hline$\beta$-Cubebene & 1388 & 1399 & 2.32 & - \\
\hline$\beta$-Elemene & 1390 & 1401 & 1.15 & - \\
\hline$\beta$-Caryophyllene & 1419 & 1428 & 38.25 & 10.65 \\
\hline$\beta$-Duprezianene & 1423 & 1510 & - & 4.27 \\
\hline$\alpha$-Humulene & 1459 & 1460 & 3.61 & - \\
\hline Germacrene & 1484 & 1487 & 13.23 & - \\
\hline Zingiberene & 1493 & 1498 & 4.19 & - \\
\hline$\beta$-Bisabolene & 1505 & 1510 & 3.32 & - \\
\hline$\delta$-Cadinene & 1522 & 1524 & 4.09 & - \\
\hline Nerolidol & 1561 & 1558 & 3.83 & - \\
\hline Caryophyllene oxide & 1583 & 1579 & 4.10 & 61.74 \\
\hline Globulol & 1585 & 1601 & - & 3.39 \\
\hline$\alpha$-Muurolol & 1646 & 1628 & 0.73 & 1.91 \\
\hline$\alpha$-Cadinol & 1652 & 1639 & 1.35 & - \\
\hline Total & - & - & 100 & 100 \\
\hline
\end{tabular}

The results of antioxidant activity of essential oils and extracts were expressed as $\mathrm{IC}_{50}$ and are shown in Table 3. In general, the antioxidant activity was better for the extracts when compared with essential oils. The decocts acetate fractions exhibited the highest antioxidant capacity. The oils had lower antioxidant potential, with $\mathrm{IC}_{50}$ greater than $1000 \mu \mathrm{g} / \mathrm{mL}$, compared with the standard quercetin ( $\mathrm{IC}_{50} 4.77 \mu \mathrm{g} / \mathrm{mL}$ ). Thus, DAFPO (ethyl acetate fraction of $P$. ornatus decoct) presented the best antioxidant activity and fungal inhibitory potential.

Antifungal activity expressed by the minimum inhibitory concentrations
(MICs) and colony formation is revealed in Table 4. Evaluation of antifungal action of the plant extracts against $M$. canis strains showed MIC and MFC of $0.15 \mathrm{mg} / \mathrm{mL}$ for all samples. The best results of samples against $T$. rubrum were for both plant leaf ethanol extracts and essential oil and decot of $P$. ornatos.

All samples exhibited growth inhibitory antimicrobial action for dermatophyte fungi. This suggests a combined action of the chemical constituents of the plant, in the extracts and essential oil, modulating an antifungal response, as demonstrated by Marwah (2007) for the $P$. cylindraceu essential oil. 
Table 3. Antioxidant DPPH test of Plectranthus spp. extracts and essential oils

\begin{tabular}{lc}
\hline Samples & ${ }^{*} \mathrm{IC}_{50}(\mu \mathrm{g} / \mathrm{mL})$ \\
\hline EEPOL & $67.04(66.27-67.81)$ \\
EEPGL & $18.01(17.58-18.44)$ \\
LDPO & $66.72(63.16-70.21)$ \\
LDPG & $16.28(15.64-16.92)$ \\
DAFPO & $12.35(12.05-12.65)$ \\
DAFPG & $15.60(15.11-16.09)$ \\
EOPO & $>1000$ \\
EOPG & $>1000$ \\
BHT & $16.00(15.98-16.02)$ \\
Quercetin & $4.77(4.24-5.30)$ \\
\hline EEPGL = Ethanol extract of Plectrantus grandis leaves; EOPG = Essential oil of $P$. grandis; DAFPG $=$ \\
Decoct acetate fraction of $P$. grandis; LDPG = Lyophilization decoct of $P$. grandis; EEPOL = Ethanol \\
extract of $P$. ornatus leaves; EOPO = Essential oil of $P$. ornatus; DAFPO = Decoct acetate fraction of $P$. \\
ornatus; LDPO = Lyophilized decoct of $P$. ornatus. CI = confidence interval.
\end{tabular}

Table 4. Minimum inhibitory concentration (MIC) and minimum fungicidal concentration (MFC) of Plectranthus spp.

\begin{tabular}{|c|c|c|c|c|c|c|}
\hline \multirow{3}{*}{ Samples* } & \multicolumn{6}{|c|}{$* * \mathrm{MIC}$ and MFC of Strains $(\mathrm{mg} / \mathrm{mL})$} \\
\hline & \multicolumn{2}{|c|}{ LABMIC 0201} & \multicolumn{2}{|c|}{ LABMIC 0202} & \multicolumn{2}{|c|}{ Isolated $M$. canis } \\
\hline & MIC & MFC & $\mathrm{MIC}$ & $\mathrm{MFC}$ & MIC & MFC \\
\hline EEPOL & 0.15 & 0.31 & 0.078 & 0.15 & 0.15 & 0.15 \\
\hline EEPGL & 0.15 & 0.31 & 0.15 & 0.31 & 0.15 & 0.15 \\
\hline LDPO & 2.5 & 5.0 & 5.0 & 5.0 & 0.15 & 0.15 \\
\hline LDPG & 5.0 & $>5.0$ & 2.5 & 5.0 & 0.15 & 0.15 \\
\hline DAFPO & 0.15 & 0.31 & 0.15 & 0.31 & 0.15 & 0.15 \\
\hline DAFPG & 5.0 & $>5.0$ & 2.5 & 5.0 & 0.15 & 0.15 \\
\hline EOPO & 1.25 & 2.5 & $>5.0$ & $>5.0$ & 0.15 & 0.15 \\
\hline EOPG & $>5.0$ & $>5.0$ & 5.0 & $>5.0$ & 0.15 & 0.15 \\
\hline
\end{tabular}

*Confidence interval. ${ }^{* *}$ Concentrations of MIC and MFC expressed in $\mathrm{mg} / \mathrm{mL}$; EEPGL $=$ Ethanol extract of Plectrantus grandis leaves; $\mathrm{EOPG}=$ Essential oil of $P$. grandis; DAFPG $=$ Decoct acetate fraction of $P$. grandis; LDPG $=$ Lyophilization decoct of $P$. grandis; EEPOL $=$ Ethanol extract of $P$. ornatus leaves; EOPO = Essential oil of $P$. ornatus; DAFPO $=$ Decoct acetate fraction of $P$. ornatus; $\mathrm{LDPO}=$ Lyophilized decoct of $P$. ornatus.

Antimycotic activity of the leaf essential oil of Ocimum gratissimum showed a minimum concentration of $78 \mathrm{mg} / \mathrm{L}$ against Microsporum gypseum and Trichophyton rubrum (PANDEY et al., 2014) and the leaf essential oil of $O$. sanctum showed antifungal activity against dermatophytes at a concentration of $200 \mathrm{mg} / \mathrm{mL}$ (BALAKUMAR et al., 2011). Some of these EOs are rich in phenols, which show strong antioxidant properties, and some of them also show antimicrobial properties.

Oils and extracts of Plectranthus spp. in this study showed antifungal activity similar to essential oils rich in phenolic compounds, such as those of Thymus vulgaris and Thymus zygis, which are widely used in herbal medicine especially for the treatment of dermatophytoses (PROENÇA-DA-CUNHA et al., 2008). Other components, such as $\alpha$-pinene, myrcene and $\alpha$-humulene, are common in the Plectranthus genus (P. rugosus, $P$. fruticosus, $P$. coleoides, $P$. tenuiflorus, $P$. defoliatus and $P$. incanus) and show bactericidal and fungicidal activities (CHENG et al., 2004; NGASSAPA et al., 2016). These constituents were also 
detected in small amounts in the analysis of $P$. grandis and $P$. ornatus.

The main compounds of essential oils from Plechtranthus spp., $\quad \beta$ Caryophyllene and Caryophyllene oxide, can be responsible by antifungal activity since that previous studies demonstrated an in vitro antimicrobial potential (SABULAL et al., 2006). Caryophyllene oxide, an oxygenated terpenoid, well known as preservative in food, drugs and cosmetics, has been tested in vitro as an antifungal against dermatophytes. Its antifungal activity has been compared to ciclopiroxolamine and sulconazole, commonly used to onychomycosis treatment (YANG et al., 1999)

The modulatory activity were performed with ethanol extracts of Plectranthus spp. (EEPOL and EEPGL) against 0202
T. rubrum strain, since they showed better MIC values (Table 5). EEPGL and EEPOL in combination with ketoconazole were able to decrease the MIC value of ketoconazole, $0.25 \mathrm{mg} / \mathrm{mL}$ and $1 \mathrm{mg} / \mathrm{mL}$, respectively. The Plectranthus spp. ethanolic extract demonstrated synergy with ketoconazole inhibiting fungal growth, thus ketoconazole exhibited a lower MIC value, when compared to its use alone, this characterized an antifungal modulatory activity.

The FICI value characterized a synergistic effect for EEPGL. Research involving antimicrobial drugs in combination with natural products modulating an antifungal action is necessary, in view of frequent side effects and resistance (PYUN \& SHIN, 2006; SOBRINHO et al., 2016).

Table 5 Interaction mechanisms resulting from combination of Plectranthus spp. extracts with ketoconazole against Trichophyton rubrum dermatophytes

\begin{tabular}{llclc}
\hline Item & \multicolumn{2}{c}{ Combination 1 } & \multicolumn{2}{c}{ Combination 2 } \\
\hline \multirow{2}{*}{ FIC } & EEPGL & $0.12 \mathrm{mg} / \mathrm{mL}$ & EEPOL & $0.2 \mathrm{mg} / \mathrm{mL}$ \\
& Ketoconazole & $0.25 \mathrm{mg} / \mathrm{mL}$ & Ketoconazole & $1.0 \mathrm{mg} / \mathrm{mL}$ \\
\hline FICI & & $0.37 \mathrm{mg} / \mathrm{mL}$ & & $1.2 \mathrm{mg} / \mathrm{mL}$ \\
Interpretation & & Synergism & Indifferent \\
\hline
\end{tabular}

EELPG $=$ Ethanol extract of Plectrantus grandis leaves; EELPO = Ethanol extract of P. ornatus leaves; FIC $=$ Fractional inhibitory concentration; Interpretation of values - Synergism $($ FICI $\leq 0.5)$; Additive $(0.5<\mathrm{FICI} \leq 1.0)$; Indifferent $(1.0<\mathrm{FICI} \leq 4.0)$; Antagonism $(\mathrm{FICI}>4.0)$.

Several authors have studied the effect of different antifungal agents that act as inhibitors through the same or different metabolic pathways, such as combinations of azoles, allylamines and azoles in the ergosterol biosynthesis pathway.

Essential oils and extracts of $P$. grandis and $P$. ornatus presented antioxidant capacity to stabilize free radicals molecules and growth inhibitory antifungal action at very low concentrations against T. rubrum and $M$. canis dermatophytes strains. In addition, the ethanol extract of $P$. grandis demonstrated synergism in combination with ketoconazole. Therefore, these extracts and oils have potential for the development of new antifungal drugs, and the demonstration of antifungal and antioxidant effects supports the traditional use of Plechtranthus species in treating skin ailments. 


\section{ACKNOWLEDGMENTS}

The authors are grateful for financial support of Fundação Cearense de Amparo a Pesquisa e ao Desenvolvimento Científico e Tecnológico (FUNCAP), Coordenação de Aperfeiçoamento de Pessoal de Nivel Superior (CAPES) and also to Conselho Nacional para o Desenvolvimento Científico e Tecnológico (CNPq).

\section{REFERENCES}

ADAMS, R. P. Identification of Essential Oil Components by Gas Chromatography/Mass Spectrometry. Illinois: Allured Publishing Corporation, 2012.

ALBUQUERQUE, R.L.; VASCONCELOS-SILVA, M.G.; MACHADO, M.I.L.; MATOS, F.J.A.; MORAIS, S.M.; NETO, J.S. Chemical composition and antioxidant activity of Plectranthus grandis and $P$. ornatus essential oils from northeastern Brazil. Flavour and fragrance journal, v.22, n.1, p.24-26, 2007.

BALAKUMAR, S.; RAJAN, S.; THIRUNALASUNDARI, T.; JEEVA, S. Antifungal activity of Ocimum sanctum Linn (Lamiaceae) on clinically isolated dermatophytic fungi. Asian Pacific journal of Tropical Medicine, v.4, n.8, p.654$657,2011$.

BOUCHARA, J.P.; MIGNON, B.; CHATURVEDI, V. Dermatophytes and Dermatophytoses: A Thematic Overview of State of the Art, and the Directions for Future Research and Developments. Mycopathologia, v.182, n.1-2, p.1-4, 2017.
BRAND-WILLIAMS, W.; CUVELIER, M.E.; BERSET, C. Use of and free radical method to evaluate antioxidant activity. LWT-Food science and Technology, v.28, n.1, p.25-30, 1995.

CALVO-IRABIÉN, L.M.; PARRATABLA, V.; ACOSTA-ARRIOLA, V.; ESCALANTE-EROSA, F.; DÍAZVERA, L.; DZIB, G.R.; PEÑARODRÍGUEZ, L.M. Phytochemical diversity of the essential oils of Mexican Oregano (Lippia graveolens Kunth) populations along an Edapho-Climatic gradient. Chemistry \& Biodiversity, v.11, n.7, p.1010-1021, 2014.

CHENG, S.S.; WU, C.L.; CHANG, H.T.; KAO, Y.T.; CHANG, S.T. Antitermitic and antifungal activities of essential oil of Calocedrus formosana leaf and its composition. Journal of Chemical Ecology, v.30, n.10, p.1957-1967, 2004.

CLINICAL AND LABORATORY STANDARDS INSTITUTE - CLSI. Reference Method for Broth Dilution Antifungal Susceptibility Testing of Filamentous Fungi. (Approved Standard. Document M38. CLSI). 2 th ed. M38-A2. Wayne, PA: Clinical and Laboratory Standards Institute, 2008.

ERNY-SABRINA, M.N.; RAZALI, M.; MIRFAT, A.H.S.; MOHD-SHUKRI, M.A. Antimicrobial activity and bioactive evaluation of Plectranthus amboinicus essential oil. American Journal of Research Communication, v.2, n.12, p.121-127, 2014.

FONTENELLE. R.O.S.; MORAIS, S.M.; BRITO, E.H.S.; KERNTOPF, M.R.; BRILHANTE, R.S.N.; CORDEIRO. R.A.; TOMÉ, A.R.; QUEIROZ, M.G.R.; NASCIMENTO, N.R.F.; SIDRIM, J.J.C.; ROCHA, M.F.G. Chemical composition, toxicological aspects and antifungal activity of essential oil from Lippia 
sidoides Cham.. Journal of

Antimicrobial Chemotherapy, v.59, n.5, p.934-940, 2007.

LUKHOBA, C.W.; SIMMONDS, M.S.; PATON, A.J. Plectranthus: a review of ethnobotanical uses. Journal of Ethnopharmacology, v.103, n.1, p.124, 2006.

MARTINEZ, R.M.; JORDÁN, M.; QUÍLEZ, M.; SOTOMAYOR, J.A. Effects of Edaphoclimatic Conditions on Thymus hyemalis L. essential oil yield and composition. Journal of Essential Oil Research, v.17, n.6, p.614-618, 2005.

MARWAH, R.G.; FATOPE, M.O.; DEADMAN, M.L.; OCHEI, J.E.; ALSAIDI, S.H. Antimicrobial activity and the major components of the essential oil of Plectranthus cylindraceus.

Journal of Applied Microbiology, v.103, n.4, p.1220-1226, 2007.

MATOS, F.J.A. Introdução à Fitoquímica Experimental. Fortaleza: UFC, 2009.

NGASSAPA, O.D.; RUNYORO, D.K.; VAGIONAS, K.; GRAIKOU, K.; CHINOU, I.B. Chemical composition and antimicrobial activity of Geniosporum rotundifolium Briq and Haumaniastrum villosum (Bene) AJ Paton (Lamiaceae) essential oils from Tanzania. Tropical Journal of Pharmaceutical Research, v.15, n.1, p.107-113, 2016.

PANDEY, A.K.; SINGH, P. TRIPATHI, N.N. Chemistry and bioactivities of essential oils of some Ocimum species: an overview. Asian Pacific Journal of Tropical Biomedicine, v.4, n.9, p.682-694, 2014.
PROENÇA-DA-CUNHA, A.; SILVA, A.; ROQUE, O. Plantas e Produtos Vegetais em Fitoterapia. 3th ed. Lisboa: Fundação Calouste Gulbenkian, 2008.

PYUN, M.S.; SHIN, S. Antifungal effects of the volatile oils from Allium plants against Trichophyton species and synergism of the oils with ketoconazole. Phytomedicine, v.13, n.6, p.394-400, 2006.

SABULAL, B.; DAN, M.; KURUP, R.; PRADEEP, N.S.; VALSAMMA, R.K.; GEORGE, V. Caryophyllene-rich rhizome oil of Zingiber nimmonii from South India: chemical characterization and antimicrobial activity.

Phytochemistry, v.67, n.22, p.24692473, 2006.

SANGLARD, D. Emerging threats in antifungal-resistant fungal pathogens. Frontiers in Medicine, v. 3, p.11, 2016.

SANTOS, N.O.; MARIANE, B.; LAGO, J.H.G,; SARTORELLI, P.; ROSA, W.; SOARES, M.G.; SILVA, A.M.; LORENZI, H.; VALLIM, M.A.; PASCON, R.C. Assessing the chemical composition and antimicrobial activity of essential oils from Brazilian Plants Eremanthus erythropappus (Asteraceae), Plectrantuns barbatus, and $P$. amboinicus (Lamiaceae).

Molecules, v.20, n.5, p.8440-8452, 2015.

SIMÕES, C.M.O.; SCHENKEL, E.P.; GOSMANN, G.; MELLO, J.C.P.; MENTZ, L.A.; PETROVICK, P.R.

Farmacognosia: da planta ao medicamento. 6.ed. Porto Alegre, RS: UFSC, 2010. 
SOBRINHO, A.C.N.; SOUZA, E.B.;

ROCHA, M.F.G.; ALBUQUERQUE, M.R.J.R.; BANDEIRA, P.N.;

SANTOS, H.S.; CAVALCANTE, C.S.P.; OLIVEIRA, S.S.; ARAG ̃̃O, P.R.; MORAIS, S.M.; FONTENELLE, R.O.S. Chemical composition, antioxidant, antifungal and hemolytic activities of essential oil from Baccharis trinervis (Lam.) Pers. (Asteraceae).

Industrial Crops and Products, v.84, p.108-115, 2016.

WHITE, R.L.; BURGESS, D.S.;

MANDURU, M.; BOSSO, J.A.

Comparison of Three Different In Vitro Methods of Detecting Synergy: TimeKill, Checkerboard, and E test.

Antimicrobial Agents and

Chemotherapy, v.40, n.8, p.1914-1918, 1996.

YANG, D.P.; MICHEL, L.; CHAUMONT, J.P.; MILLET-CLERC

J. Use of caryophyllene oxide as an antifungal agent in an in vitro experimental model of onychomycosis.

Mycopathologia, v.148, n.2, p.79-82, 2000.

Receipt date: $26 / 11 / 2017$

Approval date: 27/02/2018 